\title{
EFFECT ON WEIGHT OF A HOMEMADE DIET IN WOMEN WITH OVERWEIGHT OR OBESITY: A RANDOMIZED CONTROLLED TRIAL
}

\author{
Antonio Laguna-Camacho and María de Jesús Serrano-Plata \\ Autonomous University of the State of Mexico (Mexico)
}

\begin{abstract}
The official dietetic guidelines for weight loss include the practice of "healthy eating". However, such recommendations rarely take into account the cultural context. The aim of the present study was to measure the effect of recommending a traditional homemade diet (exemplified by typical meals consumed in Mexico) vs. recommending an iso-caloric healthy diet (represented by the eatwell plate) on the weight of Mexican women with overweight or obesity. Initially 159 women were randomly assigned to the homemade diet or the healthy diet and 30 women completed the intervention. The effect on weight of the recommended diet at 4, 8 and 12 weeks was determined by one-way analysis of variance and by random regression model. Participants on average reduced weight significantly throughout the intervention without statistical difference between the homemade diet and the healthy diet. This finding supports an anti-obesity strategy of recommending traditional diets in culturally recognised terms.

KEY WORDS: healthy diet, homemade diet, culture, dietetic guidelines, weight control.

\section{Resumen}

Las guías dietéticas oficiales para bajar peso incluyen la práctica de una "alimentación saludable", sin embargo, tales recomendaciones no siempre comprenden el contexto cultural. El objetivo de este estudio fue medir el efecto de recomendar una dieta descrita como casera (ejemplificada por preparaciones de comidas típicas consumidas en México) vs. recomendar una dieta isocalórica descrita como saludable (representada por el plato del bien comer) en el peso de mujeres mexicanas con sobrepeso u obesidad. Inicialmente fueron asignadas al azar 159 mujeres a la dieta casera o la dieta saludable y 30 mujeres completaron la intervención. El efecto sobre el peso de la dieta recomendada a 4, 8 y 12 semanas se determinó por análisis de varianza unifactorial y por modelo de
\end{abstract}

\footnotetext{
Acknowledgments: To the National Council of Science and Technology (CONACyT) for the doctoral scholarship to second author to carry out the present research project under supervision of the first author (Register DCS442572). Authors thank Gustavo A. Castro Nava, Anahí Medrano Flores, Daniela Pérez Vargas Albarrán y Aldo C. Arriaga Herrera for helping out with data collection.

Correspondence: Antonio Laguna Camacho, School of Languages, Autonomous University of the State of Mexico, 205 Jesus Carranza Street, University area, 50130 Toluca (Mexico). E-mail: alagunaca@uaemex.mx
} 
regresión aleatorio. Las participantes en promedio bajaron significativamente de peso durante la intervención sin diferencia estadística significativa entre la dieta casera y la dieta saludable. Este hallazgo apoya la estrategia contra la obesidad de recomendar dietas tradicionales en términos reconocidos culturalmente.

PALABRAS CLAVE: dieta saludable, comidas caseras, cultura, guías dietéticas, control de peso.

\section{Introduction}

Diverse governments have mainly attended obesity among their populations with dietetic recommendations (Mozaffarian and Ludwig, 2010; Raynor and Champagne, 2016). However, such promotion of a healthy diet has not decreased the prevalence of obesity and other related diseases (Sanabria, 2016). Although people recognise the practices of healthy and unhealthy eating (Laguna-Camacho et al., 2018; Laguna-Camacho and Booth, 2015), the efforts to follow a healthy diet are often unsuccessful (Mann et al., 2015). This is possibly because in the modern environment the availability and promotion of unhealthy food exceeds that of healthy food (Popkin and Reardon, 2018). Also, the reductionist perspective in nutrition of measuring with little precision the consumption of energy and nutrients (Dhurandhar et al., 2015) has limited studying other relevant aspects of eating behaviour.

Dietetic recommendations present generally the foods out of their cultural context. For example, official tools for promoting healthy eating, like the eatwell plate in Mexico, illustrate only the food groups and proportions in which they should be consumed (Annex 1; Secretaría de Salud, 2012). However, in each culture the foods are consumed in typical preparations that their members name with specific terms (Booth and Booth, 2011).

Following the cultural norms of a locality ("to be in tune") is associated with wellbeing (Levine et al., 2016). In the same way, practising the local diet could benefit weight. In line with this, the transition from a traditional diet to an industrialised diet coincides with the increment in the prevalence of obesity (Popkin et al., 2012; Satia, 2010). Therefore, a return to such traditional eating practices could help reverse unhealthy weight gainance. For instance, the adherence to a Mediterranean diet reduces body weight in mediterranean population (Bendall et al., 2017; García-Hermoso et al., 2020).

The possible benefits of the traditional diet in Mexico are less known. The UNESCO recognises Mexican culinary traditions as world heritage that families in Mexico maintain despite the increase in consumption of processed food out of the home (Lachat et al., 2012). We have addressed that these typical eating preparations include the food groups of the eatwell plate and that in adequate proportions could promote a healthy weight (Laguna Camacho, 2017; Napier et al., 2017; Serrano-Plata et al., 2019). However, up to now there has been no examination if recommending a typical mexican diet reduces weight.

In addition, the behavioural response during an intervention could depend on the interpretation that the participants give to the terms with which dietetic 
recommendations are described (Booth and Booth, 2011). Although the traditional diets include specific foods, such as fish, olives, and red wine in the mediterranean diet (Schwingshackl et al., 2019) or the chilli pepper, corn and beans in the mexican diet (Allen, 1992), their description can be extended to the characteristic dishes of the region, considering in this way not only the foods but also their preparation. We found recently that the term "homemade meals" ("comidas caseras") is conventionally used by the mexican population to refer to their diverse typical or traditional dishes (Serrano-Plata, 2019). A focus on these typical preparations could improve the representation of traditional diets integrating to the dietetic recommendation the way in which foods are combined.

Considering this, we designed an intervention for mexican adult women with excess of weight in which it was recommended either a typical diet based on examples of "homemade" food preparations or an iso-caloric "healthy" diet based on the eatwell plate. The aim was to measure the effect on body weight of a traditional Mexican diet. As typical or traditional meal preparations are part of the culture of participants they could be easier to carry out than healthy meal preparations (Serrano-Plata et al., 2019). This idea is supported by interventions in mediterranean populations that found similar or larger weight reduction with the mediterranean diet than with other diets for losing weight (Bendall et al., 2017; Esposito et al., 2011). Therefore, the hypothesis was that the participants would lose the same or more weight in the mexican homemade diet than in the healthy diet promoted by the Health Agency in Mexico.

\section{Method}

\section{Participants}

The trial was carried out in 159 mothers of student children of four primary schools in Toluca (Mexico). These mothers were selected from 206 volunteers to take part in the programme "Eating for wellbeing." The recollection of data was from august 2017 to december 2018 (figure 1). Volunteers who were between 25 and 45 years old with overweight or slight obesity and availability to prepare homemade or healthy meals were included, and those who reported to have been on a diet within the preceding three months, being chronic ill or pregnant were excluded. The largest possible number of participants were enrolled during the scheduled period for data collection. The participants were assigned to the homemade diet condition or to the healthy diet condition in a simple random sequence calculated by an online application with algorithms to generate aleatory numbers (www.randomizer.org). 
Figura 1

Participant flowchart

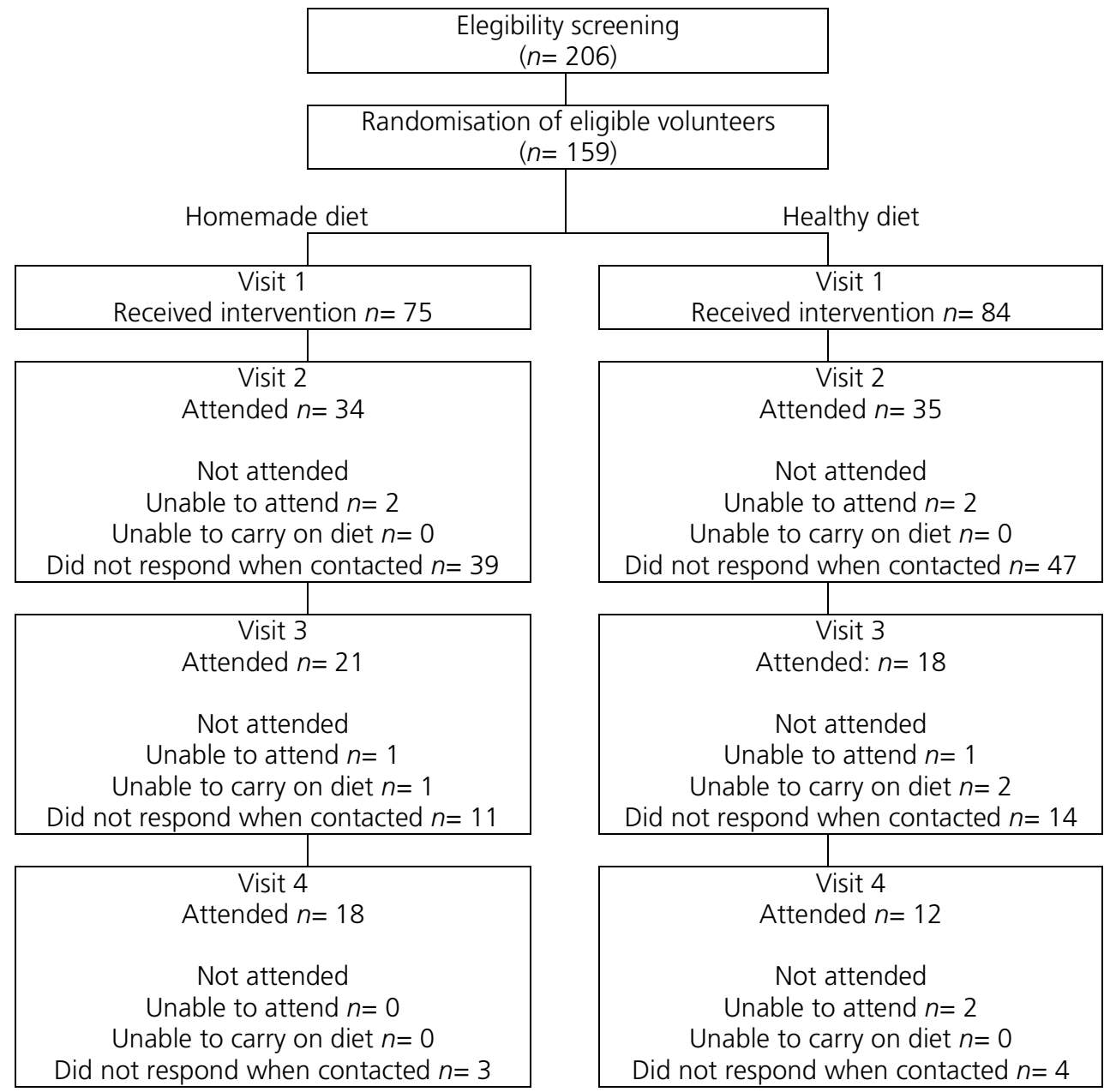

In the Table 1 are included the main characteristics of participants. There were no differences between homemade diet and healthy diet conditions in the distinct evaluated variables. No differences were found between conditions in the percentage of participants who finished the intervention. Out of the total eligible women, $43 \%$ attended visit 2, 25\% attended visit 3 and 19\% attended visit 4 (figure 1). In total, 30 participants completed the four visits, achieving the minimal sample necessary by visit calculated with the $G$ * Power 3.1 software of at least 20 participants to detect with test of intra-between repeated measures a difference in the change of weight in the 3 periods of the intervention with an effect of .04 (found in a former similar experiment; Laguna-Camacho \& Booth, 2019), alfa of .05 and power of $80 \%$. 
Table 1

Baseline characteristics of the sample $(N=159)$

\begin{tabular}{|c|c|c|}
\hline Variables & $\begin{array}{l}\text { Homemade diet } \\
\qquad(n=75)\end{array}$ & $\begin{array}{c}\text { Healthy diet } \\
(n=84)\end{array}$ \\
\hline Age (years) & $36.2(5.1)$ & $35.7(5.7)$ \\
\hline \multicolumn{3}{|l|}{ Education (\%) } \\
\hline Basic & 24.0 & 19.0 \\
\hline Medium & 40.0 & 51.2 \\
\hline Superior & 33.3 & 27.4 \\
\hline \multicolumn{3}{|l|}{ Occupation (\%) } \\
\hline Home & 57.3 & 60.7 \\
\hline Employee & 40.0 & 36.9 \\
\hline Socioeconomic level & $141(38)$ & $135(45)$ \\
\hline $\mathrm{BMI}\left(\mathrm{kg} / \mathrm{m}^{2}\right)$ & $28.8(3.4)$ & $28.8(3.8)$ \\
\hline METs (min/week) & $857(1066)$ & $1050(1336)$ \\
\hline Healthy eating motivation (scale $0-7$ ) & $5.5(0.7)$ & $5.5(0.8)$ \\
\hline Self-control (scale 0-7) & $2.8(0.5)$ & $2.9(0.5)$ \\
\hline Hedonic eating (scale 0-10) & $5.1(1.9)$ & $5.3(2.2)$ \\
\hline Wellbeing (scale 0-10) & $7.0(1.5)$ & $6.9(1.8)$ \\
\hline \multicolumn{3}{|l|}{ Preparations* (tpw) } \\
\hline Breakfast & $5.5(1.8)$ & $3.9(2.1)$ \\
\hline Lunch & $5.8(1.5)$ & $4.6(1.9)$ \\
\hline Dinner & $5.2(2.2)$ & $3.7(2.5)$ \\
\hline All & $16.5(4.3)$ & $12.2(5.2)$ \\
\hline Unhealthy foods (tpw) & $5.3(5.5)$ & $6.7(7.3)$ \\
\hline Exercise (tpw) & $1.0(2.0)$ & $1.2(2.1)$ \\
\hline Kcal/day & $1393(437)$ & $1503(613)$ \\
\hline
\end{tabular}

Notes: tpw $=$ times per week. The results correspond to media and standard deviation except for cases in which percentage is indicated. *The participants in the homemade diet group reported only episodes of homemade preparations, and participants in the healthy diet group reported only healthy preparations.

\section{Instruments}

a) Wall mounted stadiometer Seca $® 1013522$ (Seca North America, Hanover, $\mathrm{MD})$. It was used to measure height with the participant being in a vertical relaxed posture, without shoes and ankles together touching the wall, the stadiometer goes downwards to participant's head where it marks the centimeters reached.

b) Weight and body composition monitor Tanita® BF578-3601 (Tanita Corp., Tokio, Japan). It was used to measure the body weight kilograms and fat percentage of the participant wearing light clothing, with no shoes and barefoot, without having consumed food 2-3 hours, and after evacuating excreta. The equipment sends an electrical signal from the feet to the legs and abdomen passing through muscle tissue but encountering resistance (impedance) in adipose tissue, which is measured to calculate the body fat percentage. This method has good agreement with dual-energy X-ray 
absorptiometry (Thomson et al., 2007). A body fat level above 30\% in women can be classified as high (Gallager et al., 2000). Mexican adults are classified with a body mass index (BMI) from 25.0 to $29.9 \mathrm{~kg} / \mathrm{m}^{2}$ and from 30.0 to 34.9 $\mathrm{kg} / \mathrm{m}^{2}$ with overweight and mild obesity respectively (NOM 008-SSA3, 2010).

c) AMAl Questionnaire (Asociación Mexicana de Agencias de Inteligencia de Mercado y Opinión, 2018). It consists of six multiple-choice questions associated with socioeconomic variables in Mexican population (e.g., educational level of the head of the household; number of bedrooms in the home). The scores of the answers are added and the overall score is classified in socioeconomic levels from high to low: A/B 205 or more, $C+$ from 166 to 2014, C from 136 to 165 , C- from 112 to 135 , D+ from 90 to 11, D from 48 to 89 and $\mathrm{E}$ from 0 to 47.

d) Food Choice Motives Questionnaire (FCMQ; Naughton et al., 2015). FCMQ is based on questions of the Food Choice Questionnaire (Steptoe et al., 1995), Spanish version by Santos-Antonio et al. (2021). The FCMQ consists of 18 questions that evaluate aspects related to food choice and intention to eat healthy (e.g., It is important that the foods I eat keep me healthy; I always follow a healthy and balanced diet). The participant rates from 1 to 7 how much she agrees with the statement of the question. The scores of the responses are averaged, if the value is high or low indicates respectively greater or less motivation to eat healthy. Its score identifies differences by sex, age, socioeconomic status and dietary intake (Naughton et al., 2015).

e) Brief-Self-Control Scale (BSCS; Maloney et al., 2012), Spanish version by Valle et al. (2019). This scale assesses the willingness to practice behaviours that require self-regulation. It includes 13 questions with a statement (e.g., I am good at resisting temptation; I am lazy) that the participant rates from 1 (strongly disagree) to 5 (strongly agree). The scores of the responses are averaged and a high or low global score indicates more or less self-control respectively. The scale shows a positive association with healthy food consumption and a negative association with unhealthy food consumption (e.g., Giese et al., 2015).

f) Hedonic Eating Scale (HES; Brockmeyer et al., 2016). This scale assesses how much the participants enjoy common unhealthy foods, so its adaptation for the present research required only descriptions based on the same examples of unhealthy foods evaluated during the intervention. In total, eight categories of common unhealthy foods of the studied population are rated from 1 (not at all) to 10 (a lot) (e.g., How much do you like to eat chocolates, sweets, ice cream?; How much do you like to eat hamburger, pizza, French fries?). The mean score of the eight types of unhealthy food indicates the hedonic food response. The interaction between hedonic eating levels and dietary inhibition predicts the change in weight during a dietetic intervention (Brockmeyer et al., 2016).

g) 24-hour food recall. This is a common dietary evaluation method in which the participant reports the foods that she consumed with approximate amounts at each eating episode of the previous day, the portions are estimated of each food group whose established macro-nutrimental contribution permits 
calculating the consumed kilocalories (Laguna-Camacho, 2005, 2009). This recall is valid for estimating habitual energy intake in relation to energy expenditure measurement based on doubly marked water (Burrows et al., 2019).

h) International Physical Activity Questionnaire (IPAQ; Craig et al., 2003), short Spanish version (IPAC, 2017). The IPAC consists of seven questions about the participant's physical activity time in the last seven days; includes vigorous physical activity (e.g., aerobics), moderate (e.g., cycling at a steady pace), light (e.g., time spent walking) or sedentary (e.g., time sitting). The time of physical activity in the different questions is converted into MET-minutes/week using given formulas. The level of physical activity can be classified as high with at least 3000 MET min/week, moderate with 600-2999 MET min/week and low with 599 MET min/week or less (Craig et al., 2003). The IPAC shows an acceptable association with measures of recorded physical activity such as the accelerometer (Helmerhorst et al., 2012). The habitual energy expenditure of the participants was estimated with the IPAC.

\section{Procedure}

The visits to each participant were scheduled on the same weekday and at the same time every four weeks within the regular school times. In each visit, considering as reference the last four weeks, the participants rated their wellbeing level (using a scale from $0=$ "too bad" to $10=$ "very good") and reported how many days of the week (on average): 1) consumed breakfasts, lunches and dinners either homemade or healthy (according to their recommended diet group), 2) consumed unhealthy food in each eating episode (for example, fast food, savoury snacks, biscuits, sweets, soft drink, etc.) and exercised.

The recommendation given to the participants in the visits 1, 2 and 3 was to follow the assigned diet in at least 12 of the 21 eating episodes (seven breakfasts, seven lunches and seven dinners) of all the week. In these visits the participants received also a sheet of monitoring in which they recorded at the end of each day if they consumed or not the prescribed homemade or healthy breakfast, lunch and dinner, as well as if they consumed or not unhealthy foods at breakfast, between breakfast and lunch, lunch, between lunch and dinner, at dinner and after dinner, and if they exercised or not. The mean weekly frequency of each of these eating / exercise practices was additionally calculated every four weeks from the episodes recorded in the monitoring sheets. Participants were asked not to do other efforts of diet or exercise to lose weight.

Participants in the first visit responded questionnaires to assess demographic and behavioural characteristics (AMAI, FCMQ, BSCS, HFS and IPAQ) and their height was measured, and in the four visits completed a recall of food consumption of the day before, and their body weight and fat were measured.

All women signed consent that they would receive a dietetic recommendation for their wellbeing and that they would attend four visits in which their eating habits, exercise and body composition would be assessed. The Investigation Ethics Committee of the Autonomous University of the State of Mexico reviewed and 
approved the study protocol (Register 17/08). The trial was retrospectively registered at ClinicalTrials.gov: NCT03653559.

\section{DIETETIC INTERVENTION}

For the homemade diet group (intervention condition), a sheet was given with examples of typical meal preparations of breakfast, lunch and dinner described in the local vocabulary of participants (Serrano-Plata, 2019), and for the healthy diet group (control condition), a sheet was given with the image of the eatwell plate (Secretaría de Salud, 2012) as model for meal preparations of breakfast, lunch and dinner (annexe 1). In order to achieve the amount of energy and macronutrient distribution established for weight loss (Raynor and Champagne, 2016), the sheet with the diet recommendation in both conditions specified also the same number of portions for each group of foods to consume daily at breakfast, lunch and dinner (Table 2) and a list of exchanges of foods in each group to vary the preparations based on an updated selection of common foods available in the locality (Laguna-Camacho, 2005; 2009).

Table 2

Recommendation of diet in each condition of the intervention

\begin{tabular}{|c|c|c|c|}
\hline \multirow[b]{2}{*}{ Episode } & \multirow[b]{2}{*}{ Kcal } & Homemade diet & Healthy diet \\
\hline & & $\begin{array}{c}\text { [The same portions were } \\
\text { prescribed as in the healthy diet, } \\
\text { but examples of typical } \\
\text { preparations were provided } \\
\text { instead of the eatwell plate] }\end{array}$ & $\begin{array}{l}\text { [The same portions of each food } \\
\text { groups were prescribed and the } \\
\text { eatwell plate (annex 1) was } \\
\text { provided as model for breakfast, } \\
\text { lunch and dinner] }\end{array}$ \\
\hline \multirow[t]{2}{*}{ Breakfast } & \multirow[t]{2}{*}{370} & $\begin{array}{l}\text { Examples: } \\
\text { eggs, sandwich, quesadilla, stew } \\
\text { of the day before fruit, cereal, } \\
\text { fruit, bread, milkshake, coffee or } \\
\text { tea }\end{array}$ & [Image of the eatwell plate] \\
\hline & & $\begin{array}{l}\text { Portions: Vegetables 1, Fruit or } \\
\text { sugar } 1 \text {, Grains 2, Protein 1, Dairy } \\
1 / 2 \text {, Fat } 1\end{array}$ & $\begin{array}{l}\text { Portions: Vegetables 1, Fruit or } \\
\text { sugar 1, Grains 2, Protein 1, Dairy } \\
1 / 2 \text {, Fat } 1\end{array}$ \\
\hline \multirow[t]{2}{*}{ Lunch } & \multirow[t]{2}{*}{320} & $\begin{array}{l}\text { Examples: } \\
\text { soup or rice, typical stew (with } \\
\text { vegetables), beans, tortilla, plain } \\
\text { water or fruit water }\end{array}$ & [Image of the eatwell plate] \\
\hline & & $\begin{array}{l}\text { Portions: Vegetables 1, Fruit or } \\
\text { sugar 1, Grains 2, Protein 1, Fat } 1\end{array}$ & $\begin{array}{l}\text { Portions: Vegetables 1, Fruit or } \\
\text { sugar 1, Grains 2, Protein 1, Fat } 1\end{array}$ \\
\hline \multirow{2}{*}{ Dinner } & \multirow{2}{*}{370} & $\begin{array}{l}\text { Examples: } \\
\text { quesadilla, taco of stew, fruit, } \\
\text { cereal, bread, milk, coffee or tea }\end{array}$ & [Image of the eatwell plate] \\
\hline & & $\begin{array}{l}\text { Portions: Vegetables 1, Fruit or } \\
\text { sugar 1, Grains 2, Protein 1, Dairy } \\
1 / 2 \text {, Fat } 1\end{array}$ & $\begin{array}{l}\text { Portions: Vegetables 1, Fruit or } \\
\text { sugar } 1 \text {, Grains 2, Protein 1, Dairy } \\
1 / 2 \text {, Fat } 1\end{array}$ \\
\hline
\end{tabular}

Notes: Kcal= kilocalories. Both the "homemade" diet and the "healthy" diet contained approximately 1200 kilocalories with a distribution of $50-60 \%$ carbohydrates, $15-20 \%$ proteins and $<30 \%$ lipids. A list of equivalents was given in both conditions indicating the portion size for each food in each food group. To complement the energetic contribution, one portion of fruit between breakfast and lunch and one portion of fruit between lunch and dinner were also included in both conditions. 


\section{Data analyses}

The mean change in weight and body fat percent from one visit to another within each diet condition was analysed with paired $t$-test. The effect of the intervention on mean changes in weight and body fat percent between the homemade and healthy diet conditions at 4, 8 and 12 weeks was determined by one factor analysis of variance.

Additional sensitivity analyses were required due to the high attrition rate in both homemade and healthy diet conditions (the homemade diet and the healthy diet).

\section{Results}

\section{Effect of the intervention}

In the Table 3 are shown the changes in the main assessed variables. The variations of such variables can be observed from a visit to another in each one of the conditions (homemade diet and healthy diet) and differences tested between the two conditions.

The wellbeing reported at weeks 4,8 and 12 tended to increase slightly in relation to the baseline level (week 0 ) both in the homemade diet group and the healthy diet group, but there was no statistically significant difference between both conditions. Throughout the 12 weeks of the intervention, although in both groups the total reported consumption of the prescribed meal preparations tended numerically to increase, the increase was only statistically significant in the healthy diet group, however, there was neither evidence that such changes differed between the two conditions.

In the first four weeks, participants in the healthy diet group reported a larger decrease in the frequency of energy dense food consumption than in the homemade diet group, a difference that was statistically significant between conditions. Similarly, the reports of the participants in the healthy diet group also indicated an increase in exercise during the first four weeks greater than in the homemade diet group, which was statistically significant. Although the participants who completed the intervention tended to show a reduction in estimated kilocalorie consumption, such changes did not differ statistically between the two conditions at 4, 8 and 12 weeks.

The mean weight and body fat percent tended to decrease during the intervention in both conditions. The mean weight reduction was statistically significant during the first four weeks in the homemade diet group and during the 12 weeks in the healthy diet group. During the first four weeks, the mean percentage of body fat decreased marginally only in the homemade diet group. However, it was not found that the differences in mean change in body weight or fat were statistically significant at week 4,8 or 12 between the two diet conditions. 


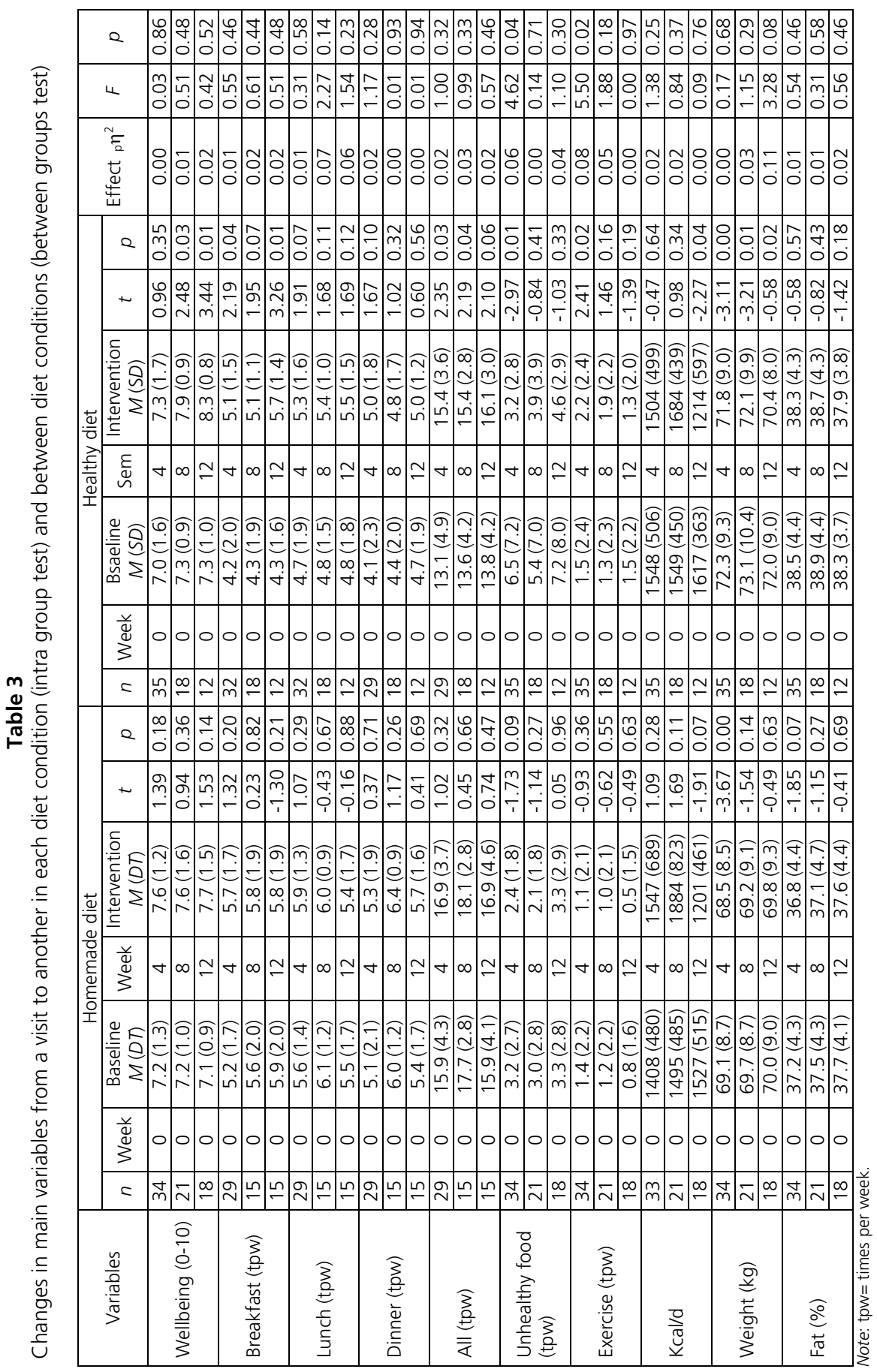


Sensitivity analyses

Overall, the baseline characteristics of participants who completed and abandoned the intervention were balanced in both conditions (Table 4). This excludes the possibility of biases in the results from confusing variables. Similarly, a non-parametric version of the analysis using Wilcoxon test for differences in the values of the variables from a visit to another within the same condition and Mann-Whitney test for differences in the changes of the values of the variables between conditions showed the same pattern of results (Table 5) than the original parametric analysis (Table 3). On this basis, a Bayesian analysis was performed to validate the null difference in body weight and fat change from a visit to another between the homemade and healthy diet conditions, in which the Bayesian factors were in general below 1.0 indicating a lower probability of the intervention results in relation to that of the null model (Table 6; Rouder et al., 2009). Finally, the random regression model was applied to measure the effect on change in weight and fat throughout the visits of the intervention with separate intercept for each condition (Atkins, 2009). The results confirmed a significant effect of the intervention at weeks 4,8 and 12 on body weight (homemade diet: $n=65,-0.482$ (1.4) kg; healthy diet: $n=73,-0.832(1.4) \mathrm{kg} ; F=0.39 ; p=.53)$ and fat (homemade diet: $n=65,-0.358$ (1.6) \%; healthy diet: $n=73,-0.258(1.4) \% ; F=0.13 ; p=.72$ ). However, there was no found difference between diet conditions of effect on body weight $(t=-0.62, p=.53)$ or fat $(t=-0.36, p=.72)$. 
Table 4

Baseline characteristics of participants according to whether they attended or not all the visits of the intervention

\begin{tabular}{|c|c|c|c|c|}
\hline \multirow{3}{*}{ Variables } & \multicolumn{4}{|c|}{ Attended all the visits } \\
\hline & \multicolumn{2}{|c|}{ Homemade diet } & \multicolumn{2}{|c|}{ Healthy diet } \\
\hline & $\begin{array}{c}\text { yes } \\
(n=18)\end{array}$ & $\begin{array}{c}\text { no } \\
(n=57)\end{array}$ & $\begin{array}{c}\text { yes } \\
(n=12)\end{array}$ & $\begin{array}{c}\text { no } \\
(n=72)\end{array}$ \\
\hline Age (years) & $35.9(4.7)$ & $36.3(5.3)$ & $37.0(5.1)$ & $35.5(5.7)$ \\
\hline \multicolumn{5}{|l|}{ Education (\%) } \\
\hline Basic & 5.6 & 29.8 & 0.0 & 22.2 \\
\hline Medium & 44.4 & 38.6 & 50.0 & 51.4 \\
\hline Superior & 50.0 & 28.1 & 50.0 & 23.6 \\
\hline \multicolumn{5}{|l|}{ Occupation (\%) } \\
\hline Home & 61.1 & 56.1 & 65.7 & 58.3 \\
\hline Employee & 38.9 & 40.4 & 34.3 & 38.9 \\
\hline Socioeconomic level & $142(36)$ & $141(39)$ & $136(35)$ & $134(46)$ \\
\hline $\mathrm{BMI}\left(\mathrm{kg} / \mathrm{m}^{2}\right)$ & $27.9(2.9)$ & $29.1(3.5)$ & $28.0(3.4)$ & $28.9(3.9)$ \\
\hline METs (min/week) & $735(775)$ & $896(1145)$ & $788(733)$ & $1094(1411)$ \\
\hline Healthy eating motivation (scale $0-7$ ) & $5.4(0.8)$ & $5.5(0.7)$ & $5.8(0.5)$ & $5.5(0.9)$ \\
\hline Self-control (scale 0-7) & $2.7(0.3)$ & $2.8(0.5)$ & $2.8(0.3)$ & $3.0(0.6)$ \\
\hline Hedonic eating (scale 0-10) & $5.4(1.5)$ & $5.0(2.0)$ & $5.9(2.2)$ & $5.2(2.2)$ \\
\hline Wellbeing (scale 0-10) & $7.1(0.9)$ & $7.0(1.7)$ & $7.3(1.0)$ & $6.8(1.9)$ \\
\hline \multicolumn{5}{|l|}{ Preparations* (tpw) } \\
\hline Breakfast & $4.9(2.0)$ & $5.6(1.7)$ & $4.3(1.6)$ & $3.8(2.2)$ \\
\hline Lunch & $5.6(1.6)$ & $5.9(1.4)$ & $4.8(1.8)$ & $4.6(1.9)$ \\
\hline Dinner & $5.6(1.6)$ & $5.1(2.4)$ & $4.7(1.9)$ & $3.5(2.5)$ \\
\hline All & $16.1(3.9)$ & $16.7(4.4)$ & $13.8(4.2)$ & $11.9(5.3)$ \\
\hline Unhealthy foods (tpw) & $3.3(2.8)$ & $6.0(6.0)$ & $7.1(8.0)$ & $6.8(7.4)$ \\
\hline Exercise (tpw) & $0.8(1.6)$ & $1.1(2.1)$ & $1.5(2.2)$ & $1.2(2.0)$ \\
\hline Kcal/day & $1527(516)$ & $1349(403)$ & $1617(363)$ & $1484(647)$ \\
\hline
\end{tabular}

Notes: Kcal= kilocalories. Both the "homemade" diet and the "healthy" diet contained approximately 1200 kilocalories with a distribution of $50-60 \%$ carbohydrates, $15-20 \%$ proteins and $<30 \%$ lipids. A list of equivalents was given in both conditions indicating the portion size for each food in each food group. To complement the energetic contribution, one portion of fruit between breakfast and lunch and one portion of fruit between lunch and dinner were also included in both conditions. 
e 일

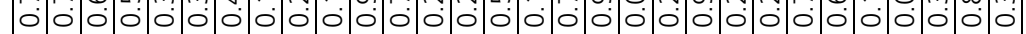

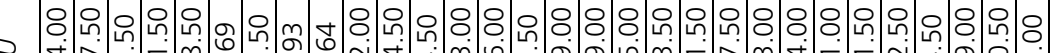

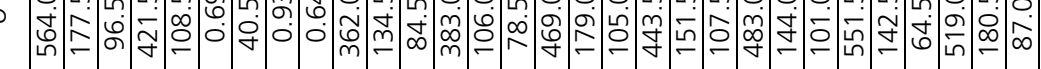
óm $m$ m

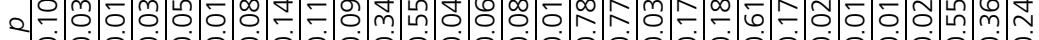

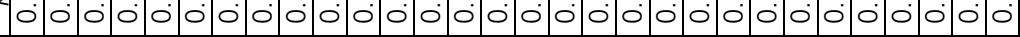

N

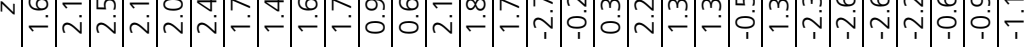

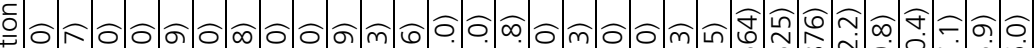

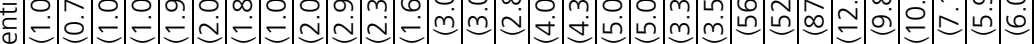

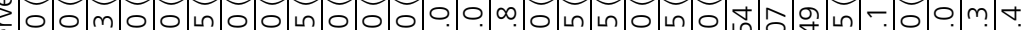

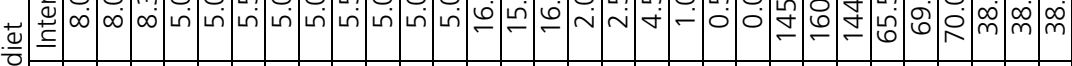

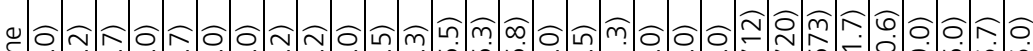

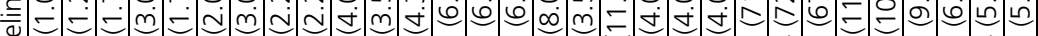

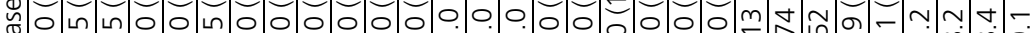

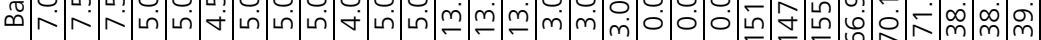

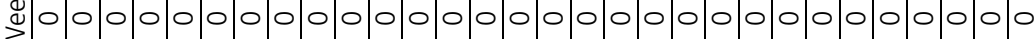

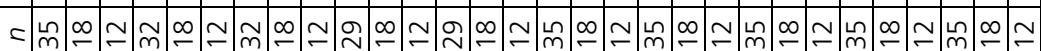

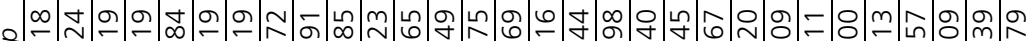

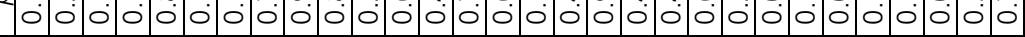

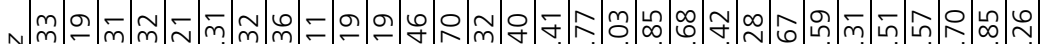

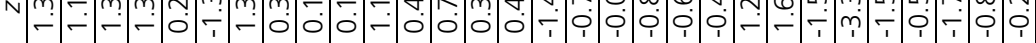

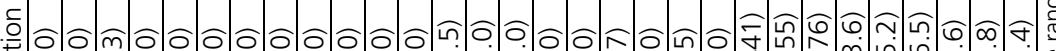

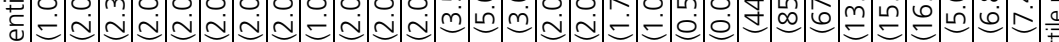

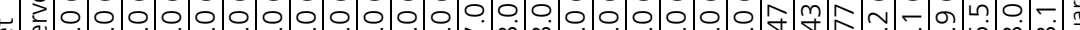

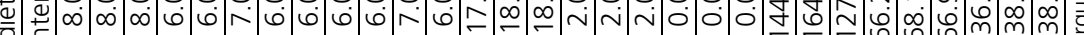
O $\frac{1}{0}$

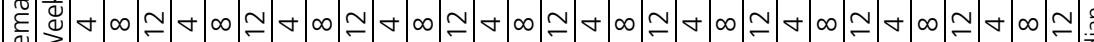

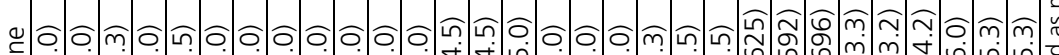

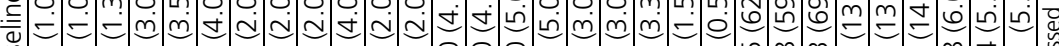

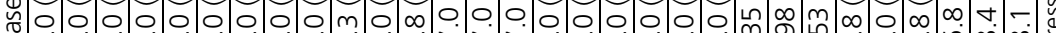

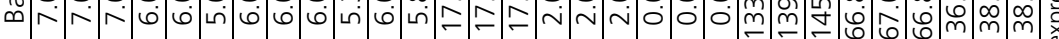

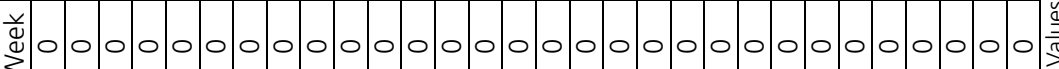

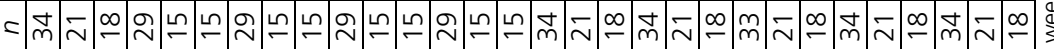

\begin{tabular}{|c|c|c|c|c|c|c|c|c|c|c|}
\hline & & & & & & & & & & \\
\hline$\frac{\frac{\tilde{U}}{0}}{\frac{\pi}{\frac{\pi}{\frac{1}{\pi}}}}$ & $\begin{array}{l}\frac{0}{1} \\
\text { o } \\
0 \\
\frac{\bar{c}}{\overline{0}} \\
\frac{0}{\bar{d}} \\
3\end{array}$ & 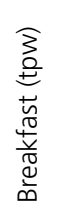 & 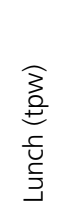 & 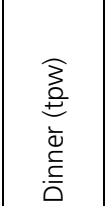 & 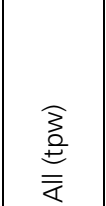 & 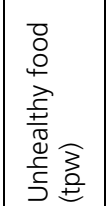 & 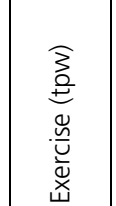 & $\frac{\bar{\theta}}{\frac{\vec{U}}{\underline{v}}}$ & $\begin{array}{l}\text { के } \\
\stackrel{2}{ \pm} \\
\pm \\
\frac{c}{0} \\
\frac{0}{1} \\
3\end{array}$ & 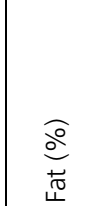 \\
\hline
\end{tabular}


Table 6

Changes in body weight and fat from a visit to another for each condition and respective Bayesian factors $\left(\mathrm{BF}_{10}\right)$

\begin{tabular}{|c|c|c|c|c|c|c|c|}
\hline \multicolumn{2}{|c|}{ Change } & $n$ & Homemade diet & $n$ & Healthy diet & $\mathrm{BF}_{10}$ & Error \% \\
\hline \multirow{2}{*}{ Visit 1 to 2} & Weight (kg) & \multirow{2}{*}{34} & $-0.609(0.968)$ & \multirow{2}{*}{35} & $-0.511(0.972)$ & 0.27 & 0.008 \\
\hline & Fat (\%) & & $-0.374(1.180)$ & & $-0.140(1.433)$ & 0.31 & 0.007 \\
\hline \multirow{2}{*}{ Visit 1 to 3} & Weight (kg) & \multirow{2}{*}{21} & $-0.500(1.490)$ & \multirow{2}{*}{18} & $-0.983(1.299)$ & 0.49 & 0.004 \\
\hline & Fat (\%) & & $-0.481(1.924)$ & & $-0.200(1.039)$ & 0.35 & 0.003 \\
\hline \multirow{2}{*}{ Visit 1 to 4} & Weight (kg) & \multirow{2}{*}{18} & $-0.222(1.910)$ & \multirow{2}{*}{12} & $-1.542(2.024)$ & 1.16 & 0.002 \\
\hline & Fat (\%) & & $-0.183(1.904)$ & & $-0.692(1.692)$ & 0.43 & 0.000 \\
\hline
\end{tabular}

\section{Discussion}

The present intervention measured the effect of recommending a homemade diet vs. recommending a healthy diet on the body weight of mexican women with overweight or obesity. The main finding was that during 4-12 weeks the effect on weight was similar between the homemade diet and the healthy diet considered the standard of dietetic management for obesity (Raynor and Champagne, 2016; Secretaría de Salud, 2012). Such evidence supports the effectiveness of the homemade diet against an unhealthy weight. This is in line with the idea that being in harmony with the traditional culture contributes to the wellbeing of the population (Levine et al., 2016) and that promoting the typical diet of a locality contributes to a healthy weight (Laguna-Camacho, 2017; Serrano-Plata et al., 2019). Similarly, interventions based on habits that promote wellbeing in normal life contribute positively to the personal satisfaction (i.e. Castillo et al., 2016).

The decrease in the frequency of unhealthy food consumption and the increase in frequency of exercise tended to be larger with the recommendation of a healthy diet than with the recommendation of a homemade diet, particularly at the beginning of the intervention. A possibility of this finding is that the notion of a healthy diet is related to the stereotype of dietary restriction, which is consistent with the changes in behaviour such as avoiding unhealthy food consumption and exercising more (Johannessen et al., 2012; Laguna-Camacho and Booth, 2015). Recommending a homemade diet could have the advantage of not generating such behavioural reactivity, which perhaps makes it easier to carry out by not requiring additional efforts than those prescribed. Although traditional diets could have advantages over conventional reductive diets, such superiority has not been established (Mancini et al., 2016), so interventions are still needed to investigate such possibility. Both traditional diets and healthy diets also compete with the high availability of unhealthy foods in the localities, which is leading to loss of traditional eating practices as well as making it difficult to practice a healthy diet (Steele et al., 2020).

Another observation in the present work was that the frequency of consumption of homemade meal preparations was relatively high from the start of the intervention. This can explain why the increase in frequency of homemade meal preparations was small and the body weight and fat reduction was modest. In the same way, in all the visits the reported frequency of consumption of healthy 
meal preparations was lower than the reported frequency of homemade meal preparations. Therefore, the participants in the group of healthy diet had larger span to increase the frequency of consumption than in the group of homemade diet. Future investigation could examine in participants with lower baseline consumption of homemade meal preparations if a larger increase in their frequency of consumption augments the reduction of body weight/fat. In the present investigation, although the reported energetic ingestion did not significantly change during the intervention, the reported frequency of consumption of unhealthy food tended to decrease perhaps due to their replacement when consuming homemade/healthy meal preparations more frequently.

A strength of the present intervention is the causal evidence about the effect on weight of the Mexican homemade diet generated by the use of a randomised controlled design. The participants were also women with excessive weight, which is representative of Mexican women in whom the prevalence of overweight or obesity reaches 76,8\% (Instituto Nacional de Estadística y Geografía, Instituto Nacional de Salud Pública y Secretaría de Salud, 2018). In addition, the participants were sampled in their children's primary schools rather than among students in university campuses where the prevalence of unhealthy weight is lower or in hospital patients in whom their health conditions or prescriptions could interfere with their usual diet.

We noticed that the rate of participants who did not complete the intervention reached the highest rates reported for interventions that require behavioural changes (Moroshko et al., 2011). Nonetheless, the proposed intrabetween individual design to measure the effect on weight of the homemade diet required a modest number of participants, which was achieved. Additionally, the sensitivity analyses showed a balance in the baseline characteristics of the participants who continued and abandoned the intervention, and confirmed a reduction in weight both in the homemade diet and in the healthy diet, with no difference in effect between these conditions. The present intervention did not have operational problems in its implementation either. The majority of the participants who dropped out of the intervention did not respond when contacted, and only a minority reported that they could not attend or did not follow the recommended diet. Similarly, in another psychonutritional intervention to reduce childhood obesity provided to mexican families directly in primary schools, despite that all the attention considerations were given, the dropout was greater than $80 \%$ of participants (de Jongh-González, 2020). Such observations are common for nutritional/behavioural practitioners who provide these interventions, in which it has been reported that 8 out of 10 their patients with overweight/obesity abandon the dietetic prescription (Sámano-Orozco, 2011). A high attrition in interventions to modify lifestyle could be common in the mexican population, however, the particular factors by which it occurs are unknown, which requires more research (Moroshko et al., 2011).

In conclusion, this is the first randomised controlled demonstrating the effect the effect of practising the recommendation of a traditional homemade diet on reducing weight of mexican women with overweight or obesity. On this basis, 
recommending a diet based on typical preparations of foods (described in terms used by the members of a locality) could be a novel intervention to decrease the prevalence of obesity in that culture. The recommendation of a traditional diet could be provided both in clinical practice and in dietetic guidelines for the population. An advantage of recommending the typical meal preparations of a region is to incorporate the cultural context to facilitate an adequate diet without necessarily referring to the term healthy.

For reproducibility of the results or replication of the intervention the dataset and the supplementary materials are available at https://osf.io/uk95w

\section{References}

Allen, L. H. (1992). The Mexican food system: Traditional and modern. Ecology of Food and Nutrition, 27, 219-234. doi: 10.1080/03670244.1992.9991246

Asociación Mexicana de Agencias de Inteligencia de Mercado y Opinión. (2018). Regla 8X7 para la medición del nivel socioeconómico NSE. http://nse.amai.org/cuestionarios/

Atkins D. C. (2009). Clinical trials methodology: Randomization, intent-to-treat, and random-effects regression. Depression \& Anxiety, 26(8), 697-700. doi: 10.1002/da.20594

Bendall, C. L., Mayr, H. L., Opie, R. S., Bes-Rastrollo, M., Itsiopoulos, C., \& Thomas, C. J. (2017). Central obesity and the Mediterranean diet: A systematic review of intervention trials. Critical Reviews in Food Science and Nutrition, 58(18), 3070-3084. doi: 10.1080/10408398.2017.1351917

Booth, D. A., \& Booth, P. (2011). Targeting cultural changes supportive of the healthiest lifestyle patterns. A biosocial evidence-base for prevention of obesity. Appetite, 56(1), 210-221. doi: 10.1016/j.appet.2010.12.003

Booth, D. A., \& Laguna-Camacho, A. (2015). Physical versus psychosocial measures of influences on human obesity. Comment on Dhurandhar et al. International Journal of Obesity, 39(7), 1177-1178. doi: 10.1038/ijo.2015.62

Brockmeyer, T., Hamze Sinno, M., Skunde, M., Wu, M., Woehning, A., Rudofsky, G., \& Friederich, H. C. (2016). Inhibitory control and hedonic response towards food interactively predict success in a weight loss programme for adults with obesity. Obesity Facts, 9(5), 299-309. doi: 10.1159/000447492

Burrows, T. L., Ho, Y. Y., Rollo, M. E., \& Collins, C. E. (2019). Validity of dietary assessment methods when compared to the method of doubly labeled water: A systematic review in adults. Frontiers in Endocrinology, 10, 850. doi: 10.3389/fendo.2019.00850

Castillo, I., Solano, S., \& Sepúlveda, A. R. (2016). Programa de prevención de alteraciones alimentarias y obesidad en estudiantes universitarios mexicanos [Prevention program for disordered eating and obesity among Mexican university students]. Behavioral Psychology/Psicología Conductual, 24(1), 5-28.

Craig, C. L., Marshall, A. L., Sjöström, M., Bauman, A. E., Booth, M. L., Ainsworth, B. E., Pratt, M., Ekelund, U., Yngve, A., Sallis, J. F., \& Oja, P. (2003). International Physical Activity Questionnaire: 12-Country reliability and validity. Medicine and Science in Sports and Exercise, 35(8), 1381-1395. doi: 10.1249/01.MSS.0000078924.61453.FB

Cuestionario internacional de actividad física (IPAQ): Formato corto auto-administrado de los últimos 7 días [International Physical Activity Questionnaire (IPAQ): Short last 7 days self-administered format]]. www.ipaq.ki.se. Julio 2017.

de Jongh-González, O. (2020). EnCamninArte: Intervención psiconutricional con terapia de arte para fomenter la autoeficacia, crianza y alimentación saludable en niños con 
obesidad [EnCaminarte: Psychonutritional intervention with art therapy for fomenting self-efficacy, parenting and healthy eating in children with obesity] [Doctoral dissertation, Ibero American University, Mexico].

Dhurandhar, N. V., Schoeller, D., Brown, A. W., Heymsfield, S. B., Thomas, D., Sørensen, T. I. A., Speakman, J. R., Jeansonne, M., Allison, D. B., \& the Energy Balance Measurement Working Group. (2015). Energy balance measurement: When something is not better than nothing. International Journal of Obesity, 39(7), 11091113. doi: 10.1038/ijo.2014.199

Esposito, K., Kastorini, C. M., Panagiotakos, D. B., \& Giugliano, D. (2011). Mediterranean diet and weight loss: Meta-analysis of randomized controlled trials. Metabolic Syndrome and Related Disorders, 9(1), 1-12. doi: 10.1089/met.2010.0031

Gallagher, D. S., Heymsfield, S. B, Moonseong, H., Susan, J., \& Murgatroyd, P. R. y Sakamoto, Y. (2000). Healthy percentage body fat ranges: An approach for developing guidelines based on body mass index. American Journal of Clinical Nutrition, 72, 694-701. doi: 10.1093/ajcn/72.3.694

García-Hermoso, A., Ezzatvar, Y., López-Gil, J. F., Ramírez-Vélez, R., Olloquequi, J., \& Izquierdo, M. (2020). Is adherence to the Mediterranean diet associated with healthy habits and physical fitness? A systematic review and meta-analysis including 565,421 youths. British Journal of Nutrition, 1-12. doi: 10.1017/S0007114520004894

Giese, H., Köning, L. M, Taut, D., Ollila, H., Baban, A., Absetz, P., Schupp, H. Y., \& Renner, B. (2015). Exploring the association between televisión advertising of healthy and unhealthy foods, self-control, and food intake in three European countries. Health and Wellbeing, 7(1), 41-62. doi: 10.1111/aphw.12036

Helmerhorst, H.H.J., Brage, S., Warren, J., Besson, H., \& Ekelund, U. (2012) A systematic review of reliability and objective criterion-related validity of physical activity questionnaires. International Journal of Behavioral Nutrition and Physical Activity, 9, 103. https://doi.org/10.1186/1479-5868-9-103

Instituto Nacional de Estadística y Geografía, Instituto Nacional de Salud Pública y Secretaría de Salud. (2018). Encuesta Nacional de Salud y Nutrición [Health and Nutrition National Survey]. https://ensanut.insp.mx/encuestas/ensanut2018/doctos/informes/ ensanut_2018_presentacion_resultados.pdf

Johannessen, K. B., Oettingen, G., \& Mayer, D. (2012). Mental contrasting of a dieting wish improves self-informed health behaviour. Psychology \& Health, 27(Suppl. 2), 43-58. doi: 10.1080/08870446.2011.626038

Lachat, C., Nago, E., Verstraeten, R., Roberfroid, D., van Camp, J., \& Kolsteren, P. (2012). Eating out of home and its association with dietary intake: A systematic review of the evidence. Obesity Reviews, 13(4), 329-346. doi: 10.1111/j.1467-789X.2011.00953.x

Laguna-Camacho, A. (2005). Sobrepeso y obesidad: Algoritmo de manejo nutricio [Overweight and obesity: Algorithm of nutritional management]. Revista de Endocrinología y Nutrición, 13, 94-104.

Laguna-Camacho, A. (2009). Obesidad y control de peso [Obesity and weight control]. México: Trillas.

Laguna-Camacho, A. (2017). Hacia una perspectiva sociocultural y económica en la política contra la alimentación no saludable [Towards a sociocultural and economical perspective against unhealthy eating]. Salud Pública de México, 59(2), 124-125. doi: $10.21149 / 7999$

Laguna-Camacho, A., \& Booth, D. A. (2015). Meals described as healthy or unhealthy match public health education in England. Appetite, 87, 283-287. doi: 10.1016/j.appet.2015.01.007 
Laguna-Camacho, A., \& Booth, D. A. (2021). Measurement of weight change after change in frequency of a locally recognised habit. How much weight is lost while one higherprotein breakfast more is eaten per week? PsyArXiv. doi: 10.31234/osf.io/kcetd

Laguna-Camacho, A., García-Manjarrez, E., Frayn, M., Knäuper, B., Domínguez-García, M. V., \& Escalante-Izeta, E. I. (2018). Perceived healthiness of breakfasts in women with overweight or obesity match expert recommendations. Open Psychology, 1(1), 25-35. doi: 10.1515/psych-2018-0003

Levine, C. S., Miyamoto, Y., Markus, H. R., Rigotti, A., Boylan, J. M., Park, J., Kitayama, S., Karasawaka, M., Kawakami, N., Coe, C. L., Love, G. D., \& Ryff, C. D. (2016). Culture and healthy eating: The role of independence and interdependence in the United States and Japan. Personality \& Social Psychology Bulletin, 42(10), 1335-1348. doi: $10.1177 / 0146167216658645$

Maloney, P. W., Grawitch, M. J., \& Barber, L. K. (2012). The multi-factor structure of the Brief Self-Control Scale: Discriminant validity of restraint and impulsivity. Journal of Research in Personality, 46(1), 111-115. doi: 10.1016/j.jrp.2011.10.001

Mancini, J. G., Filion, K. B., Atallah, R., \& Eisenberg, M. J. (2016). Systematic review of the Mediterranean diet for long-term weight loss. American Journal of Medicine, 129(4), 407-415.e4. doi: 10.1016/j.amjmed.2015.11.028

Mann, T., Tomiyama, A. J., \& Ward, A. (2015). Promoting public health in the context of the "obesity epidemic": False starts and promising new directions. Perspectives on Psychological Science, 10(6), 706-710. doi: 10.1177/1745691615586401

Miller, B. M. L., \& Brennan, L. (2015). Measuring and reporting attrition from obesity treatment programs: A call to action! Obesity Research \& Clinical Practice, 9(3), 187202. doi: 10.1016/j.orcp.2014.08.007

Moroshko, I., Brennan, L., \& O'Brien, P. (2011). Predictors of dropout in weight loss interventions: A systematic review of the literature. Obesity Reviews, 12(11), 912-934. doi: 10.1111/j.1467-789X.2011.00915.x

Mozaffarian, D., \& Ludwig, D. S. (2010). Dietary guidelines in the 21st century--a time for food. JAMA, 304(6), 681-682. doi: 10.1001/jama.2010.1116

Napier, A. D., Depledge, M., Knipper, M., Lovell, R., Ponarin, E., Sanabria, E., \& Thomas, F. (2017). Culture matters: Using a cultural contexts of health approach to enhance policy-making. WHO report. https://www.euro.who.int/en/publications/abstracts/ culture-matters-using-a-cultural-contexts-of-health-approach-to-enhance-policymaking-2017

Naughton, P., McCarthy, S. N., \& McCarthy, M. B. (2015). The creation of a healthy eating motivation score and its association with food choice and physical activity in a crosssectional sample of Irish adults. The International Journal of Behavioral Nutrition and Physical Activity, 12, 74. doi: 10.1186/s12966-015-0234-0

Norma Oficial Mexicana 008-SSA3 (2010). Tratamiento integral del sobrepeso y la obesidad [Integral treatment of overweight and obesity]. Secretaria de Salud, Mexico.

Popkin, B. M., Adair, L. S., \& Ng, S. W. (2012). Global nutrition transition and the pandemic of obesity in developing countries. Nutrition Reviews, 70(1), 3-21. doi: 10.1111/j.1753-4887.2011.00456.x

Popkin, B. M., \& Reardon, T. (2018). Obesity and the food system transformation in Latin America. Obesity Reviews, 19(8), 1028-1064. doi: 10.1111/obr.12694

Raynor, H. A., \& Champagne, C. M. (2016). Position of the Academy of Nutrition and Dietetics: Interventions for the treatment of overweight and obesity in adults. Journal of the Academy of Nutrition and Dietetics, 116(1), 129-147. doi: 10.1016/j.jand.2015.10.031 
Rouder, J. N., Speckman, P. L., Sun, D., Morey, R. D., \& Iverson, G. (2009). Bayesian $t$ tests for accepting and rejecting the null hypothesis. Psychonomic Bulletin \& Review, 16(2), 225-237. doi: 10.3758/PBR.16.2.225

Sámano-Orozco, L. F. (2011). Abandono del tratamiento dietético en pacientes diagnosticados con obesidad en un consultorio privado de nutrición [Abandoment of dietetic treatment in patients diagnosed with obesity in the private nutritional practice]. Nutrición Clínica y Dietética Hospitalaria, 31(1), 15-19.

Sanabria, E. (2016). Circulating ignorance: Complexity and agnogenesis in the obesity "epidemic". Cultural Anthropology, 31(1), 131-158. doi: 10.14506/ca31.1.07

Santos-Antonio, G., Valladares, C., Castillo, A., Aparco, J. P., Hinojosa-Mamani, P., \& Velarde-Delgado, P. (2021). Validación del cuestionario de elección de alimentos en jóvenes de Lima metropolitana, Perú, 2017. Revista Chilena de Nutrición, 48(4), 507517. doi: 10.4067/S0717-75182021000400507

Satia, J. A. (2010). Dietary acculturation and the nutrition transition: An overview. Applied Physiology, Nutrition, and Metabolism, 35(2), 219-223. doi: 10.1139/H10-007

Schwingshackl, L., Morze, J., \& Hoffmann, G. (2019). Mediterranean diet and health status: Active ingredients and pharmacological mechanisms. British Journal of Pharmacology. 177(6), 1241 -1257. doi: 10.1111/bph.14778

Secretaría de Salud. (2012). Norma Oficial Mexicana NOM-043-SSA2-2012, Servicios básicos de salud. Promoción y educación para la salud en materia alimentaria. Criterios para brindar orientación [Mexican Official Standard NOM-043-SSA2-2012, Basic Health Services. Promotion and education for healthy eating. Criteria for delivering guidance]]. http://dof.gob.mx/nota_detalle.php?codigo=5285372\&fecha=22/ 01/2013

Serrano-Plata, M. (2019). Efecto de las comidas caseras sobre peso y adiposidad corporal en mujeres adultas con sobrepeso $u$ obesidad [Effect of homemade meals on body weight and adiposity in adult women with overweight or obesity] [Tesis doctoral, Universidad Autónoma del Estado de México]. http://ri.uaemex.mx/handle/20.500.11799/105225?show=full

Serrano-Plata, M., Domínguez-García, M. V., Allirot, X., \& Laguna-Camacho, A. (2019). Comidas caseras y abatimiento de obesidad: Una revisión narrativa [Homemade meals and abatement of obesity: A narrative review]. CIENCIA ergo sum, 26(1), 1-11. doi: 10.30878/ces.v26n1a3

Steele, E. M., Khandpur, N., Sun, Q., \& Monteiro, C. A. (2020). The impact of acculturation to the US environment on the dietary share of ultra-processed foods among US adults. Preventive Medicine, 141, 106261. doi: 10.1016/j.ypmed.2020.106261

Steptoe, A., Pollard, T. M., \& Wardle, J. (1995). Development of a measure of the motives underlying the selection of food: The Food Choice Questionnaire. Appetite, 25(3), 267-284. doi: 10.1006/appe.1995.0061

UNESCO United Nations Educational, Scientific and Cultural Organization. (2010). Patrimonio cultural inmaterial de la humanidad [Intangible cultural heritage of humanity]. http://www.unesco.org/culture/ich/es/RL/la-cocina-tradicional-mexicanacultura-comunitaria-ancestral-y-viva-el-paradigma-de-michoacan-00400?RL=00400

Valle, M. V. d., Galli, J. I., Urquijo, S., \& Juric, L. C. (2019). Adaptación al español de la Escala de autocontrol y de la Escala de autocontrol - abreviada y evidencias de validez en población universitaria [Spanish adaptation of the Self-Control Scale and the Brief Self-Control Scale and evidences of validity in university population]. Revista Argentina de Ciencias del Comportamiento, 11(2), 52-64. doi: 10.32348/1852.4206.v11.n2.23413 


\section{Annexe 1}

Educative tool of healthy eating in Mexico called the eatwell plate (plato del bien comer)

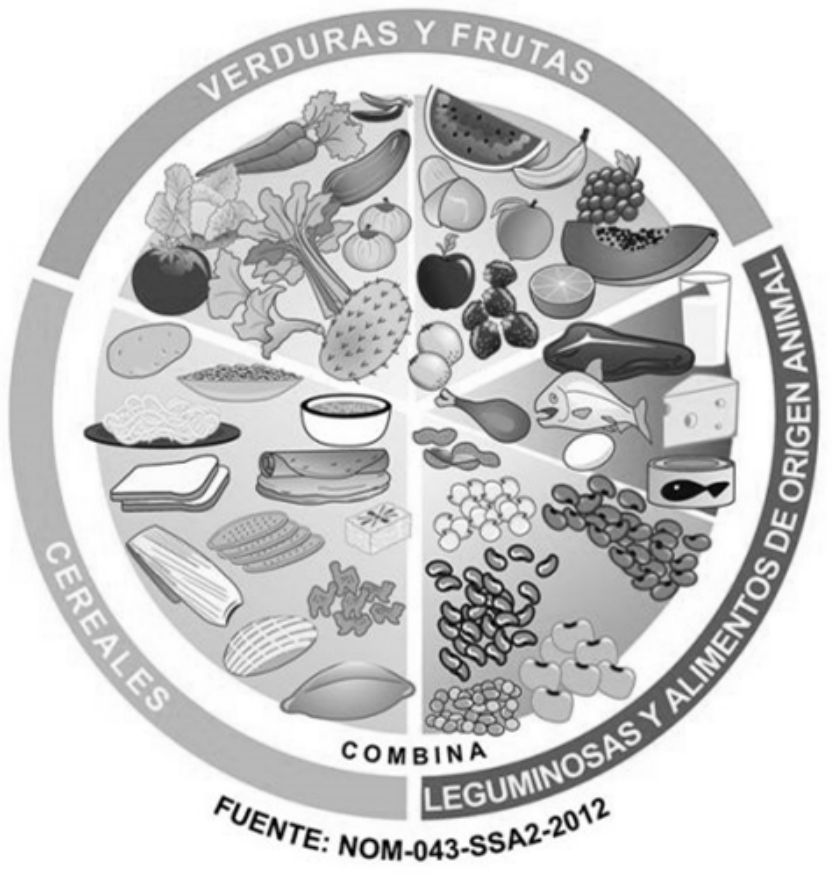

